\title{
Clinical Characteristics and Severity Profile of COVID-19 Patient with Hypertension in Palu, Central Sulawesi
}

\author{
Ingrid Faustine ${ }^{1,4}$, Amarila Malik ${ }^{2 *}$, Retnosari Andrajati' ${ }^{1}$, Septelia Inawati Wanandi ${ }^{3}$
}

1. Faculty of Pharmacy, Universitas Indonesia, Depok 16424, West Java, Indonesia

2. Laboratory of Pharmaceutical Microbiology and Biotechnology, Faculty of Pharmacy, Universitas Indonesia, Depok 16424, West Java, Indonesia

3. Faculty of Medicine, Universitas Indonesia, Jakarta 10430, Indonesia

4. Department of Pharmacy, Faculty of Mathematics and Natural Sciences, Tadulako University, Tondo, Mantikulore, Kota Palu, Sulawesi Tengah 94148

\begin{tabular}{|c|c|}
\hline Info Article & ABSTRACT \\
\hline Submitted: $06-10-2021$ & Until this year, coronavirus infection (COVID-19) is still an unsolved \\
\hline Revised: $12-12-2021$ & problem in Indonesia. Apart from Java, other islands, including Sulawesi, were \\
\hline Accepted: $18-12-2021$ & also severely affected. The very high mortality rate in Central Sulawesi \\
\hline $\begin{array}{l}\text { *Corresponding author } \\
\text { Amarila Malik }\end{array}$ & $\begin{array}{l}\text { (3.36\%) poses a challenge for health workers; therefore, they should be well } \\
\text { informed and with up-to-date information about correct therapeutic } \\
\text { decisions. One of the most common comorbidities that often occurs with the }\end{array}$ \\
\hline $\begin{array}{l}\text { Email: } \\
\text { amarila.malik@ui.ac.id }\end{array}$ & $\begin{array}{l}\text { severity and mortality of COVID-19 is hypertension. This study aims to } \\
\text { determine the clinical characteristics and severity profile and their } \\
\text { relationship with the mortality rate of COVID-19 patients with hypertension } \\
\text { in Palu, Central Sulawesi. A total of } 185 \text { data on COVID-19 patients undergoing } \\
\text { treatment at the Palu City Hospital during } 2021 \text { and meeting the criteria were } \\
\text { recruited as research samples. Patients were divided into hypertensive } \\
(43 \%) \text { and non-hypertensive ( } 57 \%) \text {. The results showed that the age group, } \\
\text { comorbid diabetes mellitus, cardiovascular, blood pressure, and blood } \\
\text { glucose levels showed a significant relationship between the two groups (p < } \\
0.05) \text {. The median length of stay was } 12 \text { days, with conditions leading to } \\
\text { discharge ( } 83 \%) \text { and death ( } 17 \%) \text {; patients who died were hospitalized in } \\
\text { moderate and severe clinical conditions. Age group, liver function, and kidney } \\
\text { function were positively correlated with severity and mortality. However, } \\
\text { hypertension did not show a significant relationship with the severity and } \\
\text { mortality of COVID-19 patients. }\end{array}$ \\
\hline
\end{tabular}

Keywords: Severe acute respiratory syndrome coronavirus 2, Hypertension, COVID-19 Severity, Central Sulawesi

\section{INTRODUCTION}

Covid-19 is a new type of coronavirus that infects humans and causes respiratory problems or sudden death. WHO declared Covid-19 a pandemic in March 2020. Until August 2021, Covid-19 cases in Indonesia reached 162 million patients with a total death of 3.2\% ("Peta Sebaran COVID-19 | Covid19.go.id," 2021). Central Sulawesi ranks 20th by contributing $1 \%$ of Covid-19 cases in Indonesia. In August 2021, Central Sulawesi is included in 5 regions with the highest number of Covid-19 cases outside Java-Bali, with a total depth of $3.11 \%$.
Twenty percent $(8,042$ cases) of them occurred in Palu City ("Covid-19 Archives - DINKES PROV SULTENG," n.d.). ("WHO Coronavirus Disease (COVID-19) Dashboard I WHO Coronavirus Disease (COVID-19) Dashboard," n.d.). Based on data from the COVID-19 distribution map in Indonesia, it is known that $50.3 \%$ of people who are confirmed positive for COVID-19 have comorbid hypertension (Karyono and Wicaksana, 2020).

Hypertension is one of the noncommunicable diseases (NCDs), which is a significant health problem because it causes $\sim 70 \%$ 
of the causes of death in the world (Shibata et al., 2020). In 2019, around $30 \%$ of the people in Central Sulawesi suffered from hypertension, and 25\% did not receive treatment (Sulteng, 2019).

Several chronic diseases such as hypertension, diabetes, coronary heart disease, and chronic obstructive pulmonary disease are often severe, and patients do not survive Covid-19 (Chen et al., 2020). The study involved 487 COVID-19 hospitalized patients in China; hypertension is related to the severity found on admission (Shi et al., 2020). It was also found in the Wuhan population that $48 \%$ of Covid-19 patients with comorbid hypertension did not survive hospitalization (Zhou et al., 2020). However, different things were shown in the French population; namely, from multivariate analysis, hypertension was not significantly associated with the development of COVID-19 (Simonnet et al., 2020).

In the RAS pathway, ACE and ACE2 work synergistically to maintain hemodynamic stability of blood pressure. When the SARS-CoV-2 virus binds to the ACE2 receptor, the infected organ has a decrease in ACE2 activity (Li et al., 2020). This decrease alters the balance of ACE and ACE2, causing an excess of Angiotensin-II, resulting in vasoconstriction and an increase in blood pressure. High ACE2 expression in hypertensive patients is thought to have the potential to increase the risk of COVID-19 severity (Gemmati and Tisato, 2020). The difference results warrant further studies into the interactions between SARS-CoV-2, ACE2, and ACE and the findings in the pathogenesis of hypertension related to the severity of COVID-19 in other populations.

Data shows that the number of people with hypertension and the number of Covid-19 cases in Palu is relatively high, but research involving this population has never been reported. Until now, there is also no clear evidence whether blood pressure affects the severe profile in Covid-19, assuming that high blood pressure will result in high severity and normal blood pressure will cause mild severity. However, it is also known that various other diseases usually accompany hypertension, so hypertension with complications may aggravate the severity profile of Covid-19 patients. Therefore, health workers must always get the latest information to conclude the correct therapeutic decision. This study aims to determine the relationship between clinical characteristics and disease severity profiles of patients with hypertension in the population in Central Sulawesi.

\section{MATERIAL AND METHODS Ethics Statement}

This research has been approved by the Health Research Ethics Committee, Faculty of Medicine, Tadulako University, with number 7916/UN.28.1.30/KL/2020. Written informed consent was obtained before the investigation.

\section{Participant and Data Sources}

This study used a cross-sectional design by collecting clinical data from 185 patients diagnosed with COVID-19 at the Palu City Hospital, Central Sulawesi, from February to July 2021. In the first part, all patients were divided into two groups based on whether they had comorbid hypertension or not. We recorded the entire course of the disease and the clinical examination results at the initial admission for each person. Data sources include demographic, clinical features, disease severity, laboratory tests obtained from the medical record system. All patients with COVID-19 met the inclusion criteria, namely: (1) Age 18 years, (2) Having a fever or other respiratory symptoms, (3) Positive SARS-CoV-2 test by RT-PCR. Exclusion criteria: (1) went home at their request, (2) incomplete medicalrecords.

The clinical classification of patients is based on the COVID-19 treatment guideline, namely: (1) mild type: only mild clinical symptoms without signs of pneumonia on imaging features; (2) common type: complicated by fever, respiratory symptoms, and imaging features of pneumonia; (3) severe type: complicated by any of the following: (a) respiratory distress, respiratory rate 30 breaths/min; (b) mean oxygen saturation $<93 \%$ at rest; or (4) critical type: complicated by any of the following: (a) respiratory failure and required mechanical ventilation; (b) shock; or (c) organ dysfunction and intensive care unit admission required. Our study combined severe and critical type patients into the severe group (Health, 2020).

\section{Statistical Analysis}

Using SPSS21.0 software (IBM, Inc., Chicago, IL, USA), categorical variables were expressed as frequency (percent), and continuous variables were defined as mean \pm standard deviation or median quartile interval. 
Table I. Baseline characteristics of COVID-19 Patients with Hypertension

\begin{tabular}{|c|c|c|c|c|}
\hline Variable & $\begin{array}{c}\text { Total } \\
(n=185)\end{array}$ & Hypertension $(n=79)$ & $\begin{array}{c}\text { Non-hypertension } \\
(n=106)\end{array}$ & $\begin{array}{c}\mathbf{p} \\
\text { Value }\end{array}$ \\
\hline Age group (y) & & & & $0.000^{b}$ \\
\hline $18-39$ & $65(35 \%)$ & $12(15 \%)$ & $53(50 \%)$ & \\
\hline $40-59$ & $77(42 \%)$ & $40(51 \%)$ & $37(35 \%)$ & \\
\hline$\geq 60$ & $43(23 \%)$ & $27(34 \%)$ & $16(15 \%)$ & \\
\hline Sex & & & & $0.752^{\mathrm{a}}$ \\
\hline Male & 83 (45\%) & $37(47 \%)$ & $46(43 \%)$ & \\
\hline Female & $102(55 \%)$ & $42(53 \%)$ & $60(57 \%)$ & \\
\hline Comorbidities & & & & $0.000^{\mathrm{a}}$ \\
\hline Non comorbidities & $69(37 \%)$ & $22(28 \%)$ & $69(65 \%)$ & \\
\hline With comorbidities & $116(63 \%)$ & $57(72 \%)$ & $37(35 \%)$ & \\
\hline \multicolumn{5}{|l|}{ Comorbidities Type } \\
\hline CPD & $6(3 \%)$ & $2(3 \%)$ & $4(4 \%)$ & $1.000^{c}$ \\
\hline Diabetes mellitus & $20(22 \%)$ & $29(37 \%)$ & $11(10 \%)$ & $0.000^{\mathrm{a}}$ \\
\hline $\begin{array}{l}\text { CVD (Other than } \\
\text { Hinertension) }\end{array}$ & $34(18 \%)$ & $26(33 \%)$ & $8(8 \%)$ & $0.000^{\mathrm{a}}$ \\
\hline CKD & $15(8 \%)$ & $8(10 \%)$ & $7(7 \%)$ & $0.551^{\mathrm{a}}$ \\
\hline \multicolumn{5}{|l|}{ Sign and Symptoms } \\
\hline Fever History & $96(52 \%)$ & $34(43 \%)$ & $62(58 \%)$ & $0.053^{\mathrm{a}}$ \\
\hline Cough & $128(69 \%)$ & $51(64 \%)$ & $77(73 \%)$ & $0.309^{a}$ \\
\hline Mucus & $27(15 \%)$ & $14(18 \%)$ & $13(12 \%)$ & $0.407^{\mathrm{a}}$ \\
\hline Fatigue & $67(36 \%)$ & $39(49 \%)$ & $28(26 \%)$ & $0.002^{\mathrm{a}}$ \\
\hline Anosmia & $20(11 \%)$ & $9(11 \%)$ & $11(10 \%)$ & $1.000^{\mathrm{a}}$ \\
\hline Nausea & $70(38 \%)$ & $28(35 \%)$ & $42(39 \%)$ & $0.670^{\mathrm{a}}$ \\
\hline Dyspnea & $95(51 \%)$ & $41(52 \%)$ & $54(51 \%)$ & $1.000^{\mathrm{a}}$ \\
\hline Vomiting & $31(17 \%)$ & $911 \%)$ & $22(21 \%)$ & $0.137^{a}$ \\
\hline Diarrhea & $13(7 \%)$ & $6(7 \%)$ & $7(6 \%)$ & $1.000^{\mathrm{a}}$ \\
\hline Headache & $20(11 \%)$ & $9(11 \%)$ & $11(10 \%)$ & $1.000^{\mathrm{a}}$ \\
\hline Myalgia & $76(41 \%)$ & $31(39 \%)$ & $45(42 \%)$ & $0.773^{\mathrm{a}}$ \\
\hline \multicolumn{5}{|l|}{ Vital Sign } \\
\hline Temperature $\left({ }^{\circ} \mathrm{C}\right)$ & $36.5 \pm 0.68$ & $36.5 \pm 0.59$ & $36.6 \pm 0,75$ & $0.254^{\mathrm{d}}$ \\
\hline Oxygen saturation (\%) & $94 \pm 7.34$ & $93 \pm 7.33$ & $95 \pm 7,4$ & $0.294^{\mathrm{d}}$ \\
\hline Respiration rate (bpm) & $25 \pm 5.56$ & $25 \pm 5.6$ & $25 \pm 5,54$ & $0.408^{\mathrm{d}}$ \\
\hline Pulse (bpm) & $87 \pm 14.36$ & $87 \pm 12.2$ & $88 \pm 15,8$ & $0.873^{\mathrm{d}}$ \\
\hline SBP (mmHg) & $125 \pm 23.5$ & $149 \pm 24.1$ & $114 \pm 15$ & $0.000^{d}$ \\
\hline DBP (mmHg) & $79 \pm 13.7$ & $85 \pm 14.6$ & $75 \pm 11,2$ & $0.000^{d}$ \\
\hline Disease Severity & & & & $0.566^{\mathrm{b}}$ \\
\hline Mild & 27 (14\%) & $9(12 \%)$ & $18(35 \%)$ & \\
\hline Moderate & $129(70 \%)$ & $57(72 \%)$ & $72(65 \%)$ & \\
\hline Severe & $29(16 \%)$ & $13(16 \%)$ & $16(15 \%)$ & \\
\hline Hospitalization time (days) & $12 \pm 4.9$ & $12 \pm 4$ & $13 \pm 5.4$ & $0.624^{\mathrm{d}}$ \\
\hline Post-treatment & & & & $0.743^{\mathrm{a}}$ \\
\hline Discharged & $153(83 \%)$ & $64(81 \%)$ & $89(84 \%)$ & \\
\hline Death & $32(17 \%)$ & $15(19 \%)$ & $17(16 \%)$ & \\
\hline
\end{tabular}

CPD (Constructive pulmonary disease), CVD (Cardiovascular disease), CKD (Chronic Kidney Disease), SBP (Systolic Blood Pressure), DBP (Diastolic Blood Pressure)

${ }^{a}$ Continuity Correction, ${ }^{b}$ Pearson Chi-Square, ${ }^{c}$ Fisher's Exact test, ${ }^{d}$ Mann Whitney test 


\section{RESULT AND DISCUSSION}

A total of 185 patients were hospitalized for confirmed COVID-19 and met the sample criteria; they were all included in this study. Forty-three percent (79 of 185) samples carried hypertension comorbid while 57\% (106 of 185) did not. The baseline characteristics, including clinical and demographic factors (Table I).

\section{Baseline Characteristics of COVID-19 Patients with Hypertension}

COVID-19 patients are predominantly female, mostly aged between 40-59 years. One hundred and sixteen (63\%) COVID-19 patients carried comorbidities. In addition to hypertension, other comorbidities are diabetes mellitus (22\%) and cardiovascular (other than hypertension) (18\%). The most common symptoms in all patients were cough (69\%) and dyspnea (61\%). A total of $129(70 \%)$ patients were admitted to treatment with moderate disease severity. The number of deaths in the hospital was 17\% (Table I).

Compared with non-hypertensive patients, hypertensive patients tend to be middle to elderly. Most of them had comorbidities such as diabetes mellitus and cardiovascular disease. The most common symptom in the hypertension group was fatigue, and this group also had higher systolic and diastolic blood pressures $(p=0.000)$. Based on the severity of COVID-19 patients, the hypertension group had a higher proportion of patients with moderate to severe severity with a higher percentage of cases of death than the non-hypertensive group. However, the two did not show a significant difference (Table I).

\section{Laboratory Parameters of COVID-19 Patients with Hypertension}

The average laboratory parameters of all COVID-19 patients showed abnormal neutrophils, lymphocytes, basophils, NLR, AST, ALT, and creatinine. In addition, the hypertension group showed significant differences in the mean values of ALT, creatinine, blood glucose, and urea compared to the non-hypertensive group $(\mathrm{p}<0,05)$ (Table II). These data suggest that COVID-19 patients with hypertension tend to exhibit more severe inflammation and organ damage symptoms than non-hypertensive COVID-19 patients, which may lead to a poor prognosis.

\section{Clinical Characteristics on the Severity of COVID-19}

Based on the baseline characteristics analysis with the severity profile as the dependent variable, it is known that comorbidities, symptoms of shortness of breath, and vital signs in the form of oxygen saturation and respiratory rate show a significant relationship with weak correlation strength. Furthermore, based on the analysis of laboratory parameters with severity profiles, it was found that several hematological parameters and AST showed a significant association with weak correlation strength $(p<0.05 ; \quad r=0.20-0.399)$ (Table III).

\section{Association of Clinical Characteristics with Post-treatment Conditions of COVID-19 Patients}

The cure rate for COVID-19 sufferers is relatively high $(83 \%)$. However, the patient's clinical condition at the time of admission affected the post-treatment condition. Table 4 shows that comorbid diseases (CKD, CVD), low oxygen saturation, NLR values $>3.13$, and AST values were associated with post-treatment patient mortality, with the strength of the correlation being weak. Urea levels showed a moderate correlation strength with post-treatment conditions. The average length of stay for discharged patients was 13 days (Table IV).

This study provides information about clinical characteristics and disease severity profiles of COVID-19 patients with hypertension in Palu, Central Sulawesi. It presents the latest status of SARS-CoV-2 infection in Indonesia, especially in Central Sulawesi. Hypertension was identified as a significant factor in the transmission of COVID-19. Association with the inhibition of the reninangiotensin-aldosterone system (RAAS), ACE-2, confirmed study increased susceptibility to COVID19. Our study shows that the dominant COVID-19 patients have hypertension in the middle age group. A study in South Korea showed that 50-59 was the highest group who received hospital treatment due to COVID-19, and $30 \%$ of hospitalized patients carry comorbid hypertension (Park et al., 2020). The study in Wuhan also showed that the average age of COVID-19 patients was 56 years, with the highest comorbidity being hypertension (30\%) (Zhou et al., 2020). The higher number of age groups may explain our study's higher prevalence of hypertension. 
Table II Laboratory parameters of COVID-19 patients with Hypertension

\begin{tabular}{lccccc}
\hline \multicolumn{1}{c}{ Variable } & $\begin{array}{c}\text { Normal } \\
\text { range }\end{array}$ & $\begin{array}{c}\text { Total } \\
(\mathbf{n = 1 8 5})\end{array}$ & $\begin{array}{c}\text { Hypertension } \\
(\mathbf{n = 7 9 )}\end{array}$ & $\begin{array}{c}\text { Non-hypertension } \\
(\mathbf{n = 1 0 6})\end{array}$ & $\begin{array}{c}\mathbf{p} \\
\text { Value }\end{array}$ \\
\hline Hematology & & & & & \\
WBC $\left(10^{9} / \mathrm{L}\right)$ & $4-11$ & $8.7 \pm 4.74$ & $7.96 \pm 3.7$ & $9.19 \pm 5.34$ & $0.124^{\mathrm{a}}$ \\
RBC $\left(10^{12} / \mathrm{L}\right)$ & $4.1-6.1$ & $4.5 \pm 0.87$ & $4.57 \pm 0.92$ & $4.45 \pm 0.84$ & $0.581^{\mathrm{a}}$ \\
Hemoglobin (g/dL) & $14-18$ & $12.6 \pm 2.54$ & $12.85 \pm 2.43$ & $12.47 \pm 2.6$ & $0.337^{\mathrm{a}}$ \\
Hematocrit (\%) & $36-47$ & $36.9 \pm 7.15$ & $37.19 \pm 7.1$ & $36.7 \pm 7.2$ & $0.546^{\mathrm{a}}$ \\
Platelets (109/L) & $150-450$ & $233 \pm 95.24$ & $225.6 \pm 92.7$ & $238.4 \pm 97.1$ & $0.330^{\mathrm{a}}$ \\
Neutrophil (\%) & $50-70$ & $39.9 \pm 33.2$ & $66.6 \pm 31.7$ & $70.5 \pm 29.6$ & $0.266^{\mathrm{a}}$ \\
Lymphocyte (\%) & $20-40$ & $12.1 \pm 22.4$ & $16.6 \pm 12.2$ & $19.3 \pm 26.6$ & $0.960^{\mathrm{a}}$ \\
Monocyte (\%) & $2-8$ & $5 \pm 5.6$ & $4.9 \pm 5.2$ & $5.1 \pm 5.8$ & $0.988^{\mathrm{a}}$ \\
Eosinophil (\%) & $0-1$ & $0.13 \pm 0.34$ & $0.16 \pm 0.47$ & $0.11 \pm 0.21$ & $0.890^{\mathrm{a}}$ \\
Basophil (\%) & $1-3$ & $0.53 \pm 0.78$ & $0.5 \pm 0.67$ & $0.53 \pm 0.86$ & $0.715^{\mathrm{a}}$ \\
NLR $\geq 3,13$ & & $129(70 \%)$ & $52(66 \%)$ & $77(73 \%)$ & $0.403^{\mathrm{b}}$ \\
Electrolyte & & & & & \\
Sodium (mEq/L) & $136-146$ & $136 \pm 9.83$ & $135.4 \pm 13$ & $136.5 \pm 6.6$ & $0.772^{\mathrm{a}}$ \\
Potassium (mEq/L) & $3.5-5$ & $3.9 \pm 0.91$ & $3.97 \pm 0.71$ & $3.99 \pm 1.03$ & $0.409^{\mathrm{a}}$ \\
Chloride (mEq/L) & $98-106$ & $98.1 \pm 5.1$ & $97.9 \pm 5.52$ & $98.2 \pm 4.78$ & $0.589^{\mathrm{a}}$ \\
Blood Chemistry & & & & & \\
AST (U/L) & $<45$ & $46.7 \pm 37$ & $48.8 \pm 93.4$ & $40 \pm 46.4$ & $0.168^{\mathrm{a}}$ \\
ALT (U/L) & $<35$ & $43.8 \pm 70.3$ & $51.04 \pm 40.3$ & $43.4 \pm 34.9$ & $\mathbf{0 . 0 4 7}^{\mathrm{a}}$ \\
Creatinine (U/L) & $0.6-1.1$ & $1.77 \pm 2.98$ & $1.8 \pm 2.51$ & $1.74 \pm 3.3$ & $0.083^{\mathrm{a}}$ \\
Urea (U/L) & $<50$ & $47 \pm 76$ & $46.63 \pm 51.9$ & $47.26 \pm 90$ & $\mathbf{0 . 0 0 3}^{\mathrm{a}}$ \\
Blood Glucose (mg/dL) & $70-200$ & $153 \pm 100.3$ & $186 \pm 123$ & $128 \pm 70.5$ & $\mathbf{0 . 0 0 0}^{\mathbf{a}}$ \\
\hline
\end{tabular}

WBC (White Blood Cell), RBC (Red Blood Cell), MCV (Mean Corpuscular Volume), MCH (Mean Corpuscular Hemoglobin), MCHC (Mean Corpuscular Hemoglobin Concentration), RDW-CV (Red Blood Cell Distribution Width Coefficient of Variation), MPV (Mean Platelet Volume), NLR (Neutrophil to lymphocyte ratio), AST (Aspartate Amino Transferase, ALT (Alanine Amino Transferase). aMann Whitney test

In addition, our study found that the risk of death of COVID-19 patients was more significant in the elderly group (30\%). Previously, older age has been reported as a significant independent predictor of mortality in SARS and MERS. Another study in macaques inoculated with SARS-CoV found that more aged macaques had a more robust response to viral infection than younger adults because of increased differential expression of genes associated with inflammation and reduced expression of type I interferon (Smits et al., 2010).

Our study found more female than male patients with hypertension in COVID-19 infection. The reduced susceptibility of women to viral infections may occur with protection from the $\mathrm{X}$ chromosome and sex hormones, which play essential roles in innate and adaptive immunity (Giefing-Kröll et al., 2015). However, it is suspected that the susceptibility of 55-year-old women to develop hypertension is caused by decreased levels of estrogen and progesterone, which affect the balance of the renin-angiotensin system in the kidneys, which functions to maintain blood pressure stability. Estrogen receptors also protect the body and assist the immune system, including T cells, B cells, macrophages, neutrophils, dendritic cells, and natural killer cells. (Channappanavar et al., 2017).

In our study, the most common symptoms were cough, dyspnea, and fever history. In the hypertension group, $49 \%$ of patients felt fatigued, but only $43 \%$ had a history of fever. This symptom is the same as the results of many studies (Karyono and Wicaksana, 2020; Niu et al., 2020; Park et al., 2020). Fever, fatigue, and dry cough are the main manifestations. Nasal obstruction, runny nose, and other upper respiratory symptoms are rare. About half of patients develop dyspnea, and severe cases progress rapidly to acute respiratory distress syndrome (ARDS), septic shock, irreversible metabolic acidosis, coagulation dysfunction, and even death (Deng and Peng, 2020; Fuk-Woo Chan, et al., 2020). 
Table III. Correlation of Clinical Characteristics with the Severity of COVID-19 Patients

\begin{tabular}{|c|c|c|c|c|c|}
\hline \multirow[b]{2}{*}{ Variable } & \multicolumn{3}{|c|}{ Severity Disease } & \multirow{2}{*}{$\begin{array}{c}\mathbf{p} \\
\text { Value }\end{array}$} & \multirow{2}{*}{$\begin{array}{c}\mathbf{r} \\
\text { Value }\end{array}$} \\
\hline & $\begin{array}{c}\text { Mild } \\
(n=27)\end{array}$ & $\begin{array}{c}\text { Moderate } \\
(n=129)\end{array}$ & $\begin{array}{c}\text { Severe } \\
(n=29)\end{array}$ & & \\
\hline \multicolumn{4}{|l|}{ Age group (y) } & $0.045^{\mathrm{a}}$ & $0.140^{\mathrm{a}}$ \\
\hline $18-39$ & $11(41 \%)$ & $48(37 \%)$ & $6(21 \%)$ & & \\
\hline $40-59$ & $12(44 \%)$ & $55(43 \%)$ & $10(34 \%)$ & & \\
\hline$\geq 60$ & $4(15 \%)$ & $26(20 \%)$ & $13(45 \%)$ & & \\
\hline Sex & & & & $0.048^{\mathrm{a}}$ & $0.114^{\mathrm{a}}$ \\
\hline Female & $12(44 \%)$ & $52(40 \%)$ & $19(65 \%)$ & & \\
\hline Male & $15(56 \%)$ & $77(60 \%)$ & $10(55 \%)$ & & \\
\hline \multicolumn{6}{|l|}{ Comorbidities Type } \\
\hline CVD (Other than Hipertension) & $2(7 \%)$ & $21(16 \%)$ & $11(38 \%)$ & $0.007^{a}$ & $0.265^{\mathrm{a}}$ \\
\hline \multicolumn{6}{|l|}{ Sign and Symptoms } \\
\hline Dyspnea & $2(7)$ & $74(57 \%)$ & $19(66 \%)$ & $0.000^{\mathrm{a}}$ & $0.292^{\mathrm{a}}$ \\
\hline \multicolumn{6}{|l|}{ Vital Sign } \\
\hline Oxygen saturation (\%) & $96 \pm 1.5$ & $95 \pm 4.5$ & $86 \pm 13$ & $0.000^{\mathrm{b}}$ & $-0.314^{b}$ \\
\hline Respiration rate (bpm) & $22 \pm 2.7$ & $25 \pm 5.4$ & $29 \pm 6$ & $0.000^{\mathrm{b}}$ & $0.397^{b}$ \\
\hline \multicolumn{6}{|l|}{ Hematology } \\
\hline Hematocrit (\%) & $33.9 \pm 5.3$ & $37.4 \pm 7.1$ & $37.6 \pm 8.1$ & $0.009^{b}$ & $0.207^{b}$ \\
\hline Neutrophil (\%) & $52 \pm 33$ & $70 \pm 32$ & $77 \pm 9.6$ & $0.000^{\mathrm{b}}$ & $0.327^{b}$ \\
\hline$N L R \geq 3,13$ & $18(67 \%)$ & $84(65 \%)$ & $27(93 \%)$ & $0.012^{\mathrm{a}}$ & $0.166^{\mathrm{a}}$ \\
\hline \multicolumn{6}{|l|}{ Blood Chemistry } \\
\hline AST (U/L) & $21.4 \pm 10.9$ & $44.6 \pm 77$ & $61 \pm 66$ & $0.021^{b}$ & $0.321^{b}$ \\
\hline ALT (U/L) & $29.9 \pm 11$ & $46.6 \pm 36.7$ & $62.3 \pm 49$ & $0.000^{\mathrm{b}}$ & $0.198^{b}$ \\
\hline Urea (U/L) & $31.7 \pm 28$ & $40.35 \pm 55.5$ & $89.8 \pm 144$ & $0.006^{\mathrm{b}}$ & $0.152^{b}$ \\
\hline Hospitalization time (days) & $13 \pm 3.9$ & $12 \pm 4.4$ & $8 \pm 6$ & $0.001^{\mathrm{b}}$ & $-0.223^{b}$ \\
\hline
\end{tabular}

CVD (Cardiovascular disease), MCV (Mean Corpuscular Volume), MCHC (Mean Corpuscular Hemoglobin Concentration), RDW-CV (Red Blood Cell Distribution Width Coefficient of Variation), MPV (Mean Platelet Volume), NLR (Neutrophil to lymphocyte ratio), AST (Aspartate Amino Transferase, ALT (Alanine Amino Transferase). aSomers'd test, bSpearman Test

Patients who do not have a fever or a low-grade fever can increase the difficulty of identifying and diagnosing COVID-19 in clinical practice. In this study, it was found that oxygen saturation and respiration rate had a relationship with the mortality rate of COVID-19 patients. COVID-19 patients who experience decreased oxygen saturation or increased respiratory rate upon hospital admission significantly increase the risk of death (Zhou et al., 2020). COVID-19 patients often experience hypoxia without apparent symptoms, so the opportunity to start treatment early tends to be too late.

In addition, $63 \%$ of patients infected by COVID-19 undergoing treatment have underlying chronic diseases, mainly cardiovascular and diabetes. The hypertension group tends to have other comorbidities, namely diabetes mellitus, cardiovascular disease (other than hypertension). Our study found that the hypertensive group had higher glucose levels than the non-hypertension group. Comorbid hypertension, like diabetes and chronic kidney disease, is associated with severe COVID-19 and poor outcomes (Park et al., 2020). Researchers have identified that poor glycemic control is related to the prognosis of severe COVID19 patients in the hypertension group. COVID-19 patients with diabetes have a higher risk of hospital stay and more extended periods (Hill, et al., 2020; Wicaksana, et al., 2020).

Comorbid diseases such as hypertension, diabetes, and chronic kidney disease, are associated with severe COVID-19 and poor outcomes. In this study, we did not find a relationship between hypertension and blood pressure with the severity and mortality of Covid-19 patients. 
Table 4. Correlation of Clinical Characteristics with Post-treatment Conditions of COVID-19 Patients

\begin{tabular}{|c|c|c|c|c|}
\hline \multirow{2}{*}{ Variable } & \multicolumn{2}{|c|}{ Post-treatment } & \multirow{2}{*}{$\underset{\text { Value }}{\mathbf{p}}$} & \multirow{2}{*}{$\begin{array}{c}\mathbf{r} \\
\text { Value } \\
\end{array}$} \\
\hline & Discharged ( $n=153$ ) & Death $(n=32)$ & & \\
\hline Age group (y) & & & $0.008^{\mathrm{a}}$ & $0.198^{\mathrm{a}}$ \\
\hline $\begin{array}{l}18-39 \\
40-59 \\
\geq 60\end{array}$ & $\begin{array}{l}62(40 \%) \\
64(42 \%) \\
27(18 \%)\end{array}$ & $\begin{array}{c}3(9 \%) \\
13(41 \%) \\
16(50 \%)\end{array}$ & & \\
\hline \multicolumn{5}{|l|}{ Comorbidities Type } \\
\hline CKD & $9(6 \%)$ & $6(19 \%)$ & $0.027 \mathrm{a}$ & $0.247 \mathrm{a}$ \\
\hline CVD (Other than Hipertension) & $22(14 \%)$ & $12(38 \%)$ & $0.005^{\mathrm{a}}$ & $0.220^{\mathrm{a}}$ \\
\hline \multicolumn{5}{|l|}{ Vital Sign } \\
\hline Temperature $\left({ }^{\circ} \mathrm{C}\right)$ & $37 \pm 0.63$ & $36 \pm 0.88$ & $0.027^{b}$ & $-0.163^{b}$ \\
\hline Oxygen saturation (\%) & $96 \pm 3.37$ & $86 \pm 13.64$ & $0.000^{b}$ & $-0.323^{b}$ \\
\hline Respiration rate (bpm) & $24 \pm 4.23$ & $30 \pm 7.8$ & $0.000^{b}$ & $-0.114^{b}$ \\
\hline Severity Disease & & & $0.000^{\mathrm{a}}$ & $0.281^{\mathrm{a}}$ \\
\hline Mild & $27(18 \%)$ & $0(0 \%)$ & & \\
\hline Moderate & $116(76 \%)$ & $1341 \%)$ & & \\
\hline Severe & $10(6 \%)$ & $9(28 \%)$ & & \\
\hline \multicolumn{5}{|l|}{ Hematology } \\
\hline Platelets $\left(10^{9} / \mathrm{L}\right)$ & $241.1 \pm 95.5$ & $193.96 \pm 85$ & $0.015^{b}$ & $-0.179 b$ \\
\hline Neutrophil (\%) & $66.8 \pm 29.6$ & $78.6 \pm 33.5$ & $0,008^{b}$ & $0.195^{b}$ \\
\hline Lymphocyte (\%) & $19.9 \pm 23.3$ & $9,5 \pm 5.38$ & $0,000^{b}$ & $-0.318^{b}$ \\
\hline Eosinophil (\%) & $0.15 \pm 0.37$ & $0.05 \pm 0.09$ & $0.033^{b}$ & $-0.157 b$ \\
\hline NLR $>3,13$ & $97(63 \%)$ & $32(100 \%)$ & $0,000^{\mathrm{a}}$ & $0.248^{a}$ \\
\hline \multicolumn{5}{|l|}{ Blood Chemistry } \\
\hline AST (U/L) & $40.22 \pm 71.3$ & $60.68 \pm 63.5$ & $0.012^{b}$ & $0.277^{b}$ \\
\hline $\operatorname{ALT}(\mathrm{U} / \mathrm{L})$ & $43.39 \pm 35$ & $62.29 \pm 44.7$ & $0.000^{b}$ & $0.186^{b}$ \\
\hline Creatinine (U/L) & $1.54 \pm 2.43$ & $2.88 \pm 4.7$ & $0.033^{b}$ & $0.157^{b}$ \\
\hline Urea (U/L) & $34 \pm 46.8$ & $108.9 \pm 136.7$ & $0.000^{b}$ & $0.435^{b}$ \\
\hline Hospitalization time (days) & $13 \pm 3.23$ & $7 \pm 7.45$ & $0.000^{c}$ & \\
\hline
\end{tabular}

CKD (Chronic Kidney Disease), CVD (Cardiovascular disease), MCV (Mean Corpuscular Volume), RDW-CV (Red Blood Cell Distribution Width Coefficient of Variation), NLR (Neutrophil to lymphocyte ratio), AST (Aspartate Amino Transferase, ALT (Alanine Amino Transferase). aLambda test, bSpearman Test, cMann Whitney test

This result is in line with the research conducted by de Terwangne (2020), which found that although the percentage of patients experiencing hypertension admitted with a critical condition was higher than severe and moderate, there was no significant relationship between hypertension and blood pressure with the severity of Covid-19 (de Terwangne et al., 2020). Another study involving the population of Surabaya showed no significant relationship between hypertension and blood pressure with the severity of Covid-19 (Tsany, 2021). In contrast to the research reported by Park (2020) showed that hypertension had a significant relationship with the severity of Covid-19 patients, where $73.1 \%$ of hypertensive patients experienced a critical illness or death during hospitalization or isolation due to Covid-19 (Park et al., 2020). We think that the use of antihypertensive groups may play a role in RAS influencing the severity of Covid19. De Terwangne (2020) found that chronic treatment using ACE inhibitors in hypertensive patients had a significant relationship with the severity of Covid-19 patients (de Terwangne et al., 2020). Fang (2020) revealed that patients with heart disease, hypertension, or diabetes, treated with drugs that increase ACE2 are at higher risk for severe COVID-19 infection. Therefore, it should be monitored for the use of drugs that modulate ACE2, such as ACE inhibitors or ARBs (Lei and Karakiulakis, 2020).

We found that CVD comorbidity was associated with the severity of COVID-19. Another study concluded that patients with comorbid had a nearly three times higher risk for ICU admission 
(OR 2.79; 95\% CI: 1.85-4.22) and death (OR 3.21; 95\% CI: 1.82-5,64) (Roncon, et al., 2020). Most cases were discharged as asymptomatic patients, but $17 \%$ died. It is related to the severity of the patient at the time of admission to the hospital, namely moderate-severe. For the hypertension group, moderate and severe severity was directly proportional to the percentage of mortality in this group. A previous study found that more than $50 \%$ of COVID-19 patients had sepsis (Zhou et al., 2020). Viral infection is the only reason for sepsis. Sepsis is a common complication directly caused by infection with SARS-CoV-2. Therefore, sepsis is expected to experience these critically ill COVID-19 patients (Beltrán-García et al., 2020). However, further research is needed on the pathogenesis of sepsis in COVID-19.

Based on laboratory tests, most patients have increased neutrophils and decreased lymphocytes, but this is not associated with comorbid hypertension. Instead, increased neutrophils, NLR values, and decreased lymphocytes are related to the severity of disease and mortality rate of COVID-19. These results indicate that SARS-CoV-2 acts on lymphocytes, especially $\mathrm{T}$ lymphocytes. Virus particles spread through the respiratory mucosa and infect other cells, induce a cytokine storm in the body, generate a series of immune responses, and cause changes in peripheral white blood cells and immune cells such as lymphocytes (Chen et al., 2020).

In this study, the hypertension group showed an abnormal liver and kidney function tests pattern. An increase in Ureum, creatinine, ALT, and AST values were also associated with the severity and mortality rate of COVID-19. Several mechanisms related to renal impairment in COVID19 , such as the comorbid CKD, SARS-CoV-2 induces renal resident cell cytotoxic, and symptoms such as fever and shock can cause renal hypoperfusion (Liu et al., 2021). The theory about the relationship between increased AST and ALT values when admission to SARS-CoV-2 infection is unclear. The ACE2 receptor for viral entry is more expressed in cholangiocytes than in hepatocytes (Moon and Barritt, 2021; Sharma et al., 2021). We, therefore, assumed that the direct cytopathic effect of SARSCoV-2 might not be the primary mechanism of COVID-19-associated liver damage. Liver dysfunction in COVID-19 can be associated with an uncontrolled immune reaction, sepsis, or druginduced liver injury, in addition to the direct cytopathic effect of the virus, but further monitoring is needed (Xu, et al., 2021).

\section{CONCLUSION}

Hypertension is associated with clinical characteristics but is not a poor prognostic factor for the severity profile and mortality rate. It appeared that age group, liver function, and kidney function were positively correlated with severity and mortality in COVID-19 patients in Palu, Central Sulawesi.

\section{ACKNOWLEDGEMENT}

We acknowledge all the healthcare workers involved in diagnosing and treating COVID-19 in Palu, Central Sulawesi.

\section{ADDITIONAL INFORMATION}

Part of the results described in this study has been presented at the International Teleconference on Technology and Policy for Supporting Implementation of Covid-19 Response and Recovery Plan in Southeast Asia (ITTP-Covid19), $6^{\text {th }}-8^{\text {th }}$ August 2021

\section{REFERENCES}

Beltrán-García, J., Osca-Verdegal, R., Pallardó, F. V., Ferreres, J., Rodríguez, M., Mulet, S., ... GarcíaGiménez, J. L. (2020). Sepsis and Coronavirus Disease 2019: Common Features and AntiInflammatory Therapeutic Approaches. Critical Care Medicine, 48(12), 1841-1844. https://doi.org/10.1097/CCM.00000000000 04625

Channappanavar, R., Fett, C., Mack, M., Ten Eyck, P. P., Meyerholz, D. K., and Perlman, S. (2017). Sex-Based Differences in Susceptibility to Severe Acute Respiratory Syndrome Coronavirus Infection. The Journal of Immunology, 198(10), 4046-4053. https://doi.org/10.4049/jimmunol.1601896

Chen, N., Zhou, M., Dong, X., Qu, J., Gong, F., Han, Y., ... Zhang, L. (2020). Epidemiological and clinical characteristics of 99 cases of 2019 novel coronavirus pneumonia in Wuhan, China: a descriptive study. The Lancet, 395(10223), 507-513. https://doi.org/10.1016/S01406736(20)30211-7

Covid-19 Archives - DINKES PROV SULTENG. (n.d.). Retrieved August 24, 2021, from https://dinkes.sultengprov.go.id/category/c ovid-19/

de Terwangne, C., Laouni, J., Jouffe, L., Lechien, J. R., Bouillon, V., Place, S., ... Sorgente, A. (2020). Predictive accuracy of covid-19 world health 
organization (Who) severity classification and comparison with a bayesian-methodbased severity score (epi-score). Pathogens, 9(11), 1-17. https://doi.org/10.3390/pathogens9110880

Deng, S.-Q., and Peng, H.-J. (2020). Characteristics of and Public Health Responses to the Coronavirus Disease 2019 Outbreak in China. Journal of Clinical Medicine, 9(2), 575. https://doi.org/10.3390/jcm9020575

Fuk-Woo Chan, J., Yuan, S., Kok, K.-H., Kai-Wang To, K., Chu, H., Yang, J., ... Yuen, K.-Y. (2020). Articles A familial cluster of pneumonia associated with the 2019 novel coronavirus indicating person-to-person transmission: a study of a family cluster. Www. Thelancet.Com, 395, 2020. https://doi.org/10.1016/S01406736(20)30154-9

Gemmati, D., and Tisato, V. (2020). Genetic hypothesis and pharmacogenetics side of renin-angiotensin-system in COVID-19. Genes, 11(9), 1-17. https://doi.org/10.3390/genes11091044

Giefing-Kröll, C., Berger, P., Lepperdinger, G., and Grubeck-Loebenstein, B. (2015, June 1). How sex and age affect immune responses, susceptibility to infections, and response to vaccination. Aging Cell, Vol. 14, pp. 309-321. https://doi.org/10.1111/acel.12326

Health, N. I. of. (2020). Coronavirus Disease 2019 (COVID-19) Treatment Guidelines. Disponible en: https://covid19treatmentguidelines.nih.gov /. In Nih (Vol. 2019).

Hill, M. A., Mantzoros, C., and Sowers, J. R. (2020). Commentary: COVID-19 in patients with diabetes. Metabolism: Clinical and Experimental, $\quad 107,154217$. https://doi.org/10.1016/j.metabol.2020.154 217

Karyono, D. R., and Wicaksana, A. L. (2020). Current prevalence, characteristics, and comorbidities of patients with COVID-19 in Indonesia. Journal of Community Empowerment for Health, 3(2), 77. https://doi.org/10.22146/jcoemph.57325

Lei Fang, George Karakiulakis, M. R. (2020). Are patients with hypertension and diabetes mellitus at increased risk for COVID-19 infection? 8(April), 19-21. https://doi.org/10.1111/all.14238.Wan

Li, X., Xu, S., Yu, M., Wang, K., Tao, Y., and Zhou, Y. (2020). Risk factors for severity and mortality in adult COVID-19 inpatients in Wuhan. J
Allergy Clin Immunol, 146(110-8), 109-118. https://doi.org/https:doi.org/10.1016/j.jaci. 2020.04.006

Liu, Y.-F., Zhang, Z., Pan, X.-L., Xing, G.-L., Zhang, Y., Liu, Z.-S., and Tu, S.-H. (2021). The chronic kidney disease and acute kidney injury involvement in COVID-19 pandemic: A systematic review and meta-analysis. PLOS ONE, 16(1), e0244779. https://doi.org/10.1371/JOURNAL.PONE.02 44779

Moon, A. M., and Barritt, A. S. (2021, June 1). Elevated Liver Enzymes in Patients with COVID-19: Look, but Not Too Hard. Digestive Diseases and Sciences, Vol. 66, pp. 1767-1769. https://doi.org/10.1007/s10620-02006585-9

Niu, S., Tian, S., Lou, J., Kang, X., Zhang, L., Lian, H., and Zhang, J. (2020). Clinical characteristics of older patients infected with COVID-19: A descriptive study. https://doi.org/10.1016/j.archger.2020.104 058

Park, H.-Y., Lee, J. H., Lim, N.-K., Lim, D. S., Hong, S. O., Park, M.-J., ... Jeong, E. K. (2020). Presenting characteristics and clinical outcome of patients with COVID-19 in South Korea: A nationwide retrospective observational study. The Lancet Regional Health - Western Pacific, 5(November), 100061. https://doi.org/10.1016/j.lanwpc.2020.100 061

Peta Sebaran COVID-19 | Covid19.go.id. (2021). Retrieved August 12, 2021, from https://covid19.go.id/peta-sebaran-covid19

Roncon, L., Zuin, M., Rigatelli, G., and Zuliani, G. (2020). Diabetic patients with COVID-19 infection are at higher risk of ICU admission and poor short-term outcome. https://doi.org/10.1016/j.jcv.2020.104354

Sharma, A., Jaiswal, P., Kerakhan, Y., Saravanan, L., Murtaza, Z., Zergham, A., ... Malik, P. (2021). Liver disease and outcomes among COVID-19 hospitalized patients - A systematic review and meta-analysis. Annals of Hepatology, 21. https://doi.org/10.1016/j.aohep.2020.10.00 1

Shi, Y., Yu, X., Zhao, H., Wang, H., Zhao, R., and Sheng, J. (2020). Host susceptibility to severe COVID19 and establishment of a host risk score: Findings of 487 cases outside Wuhan. Critical Care, 24(1), 2-5. https://doi.org/10.1186/s13054-020-2833- 
7

Shibata, S., Arima, H., Asayama, K., Hoshide, S., Ichihara, A., and Ishimitsu, T. (2020). Hypertension and related diseases in the era of COVID-19: a report from the Japanese Society of Hypertension Task Force on COVID-19. Hypertension Research. https://doi.org/10.1038/s41440-020-05150

Simonnet, A., Chetboun, M., Poissy, J., Raverdy, V., Noulette, J., Duhamel, A., ... Verkindt, H. (2020). High Prevalence of Obesity in Severe Acute Respiratory Syndrome Coronavirus-2 (SARS-CoV-2) Requiring Invasive Mechanical Ventilation. Obesity, 28(7), 1195-1199. https://doi.org/10.1002/oby.22831

Smits, S. L., De Lang, A., Van Den Brand, J. M. A., Leijten, L. M., Van Ijcken, W. F., Eijkemans, M. J. C., ... Haagmans, B. L. (2010). Exacerbated innate host response to SARS-CoV in aged non-human primates. PLoS Pathogens, 6(2), e1000756.

https://doi.org/10.1371/journal.ppat.10007 56

Sulteng, D. S. (2019). Dinkes Sulteng 2019. Dinas Kesehatan Sulawesi Tengah, 1-222.

Tsany, I. (2021). Pengaruh Komorbid Hipertensi Terhadap Tingkat Keparahan pada Pasien Terkonfirmasi COVID 19 di RSPAL DR Ramelan Surabaya Periode Maret - September 2020. Retrieved from https://emea.mitsubishielectric.com/ar/pro ducts-solutions/factory- automation/index.html

WHO Coronavirus Disease (COVID-19) Dashboard |

WHO Coronavirus Disease (COVID-19)

Dashboard. (n.d.). Retrieved August 20, 2021,

from

https://covid19. who.int/?gclid=CjwKCAiAg8 OBBhA8EiwAlKw3kgEbgOmOUBe7oGXkauy KVEIwMVWVxsSUNf3VzOvJ_S7zP6Fl89Hydx oCrpoQAvD_BwE

Wicaksana, A. L., Hertanti, N. S., Ferdiana, A., and Pramono, R. B. (2020). Diabetes management and specific considerations for patients with diabetes during coronavirus diseases pandemic: A scoping review. Diabetes and Metabolic Syndrome: Clinical Research and Reviews, 14(5), 1109-1120. https://doi.org/10.1016/j.dsx.2020.06.070

Xu, W., Huang, C., Fei, L., Li, Q., and Chen, L. (2021). Dynamic changes in liver function tests and their correlation with illness severity and mortality in patients with covid-19: A retrospective cohort study. Clinical Interventions in Aging, 16, 675-685. https://doi.org/10.2147/CIA.S303629

Zhou, F., Yu, T., Du, R., Fan, G., Liu, Y., Liu, Z., ... Cao, B. (2020). Clinical course and risk factors for mortality of adult inpatients with COVID-19 in Wuhan, China: a retrospective cohort study. The Lancet, 395(10229), 1054-1062. https://doi.org/10.1016/S01406736(20)30566-3 